\title{
Estimate of false-positive breast cancer diagnoses from accuracy studies: a systematic review
}

\author{
Nereo Segnan, Silvia Minozzi, Antonio Ponti, Cristina Bellisario, Sara Balduzzi, \\ Marien González-Lorenzo, Silvia Gianola, Paola Armaroli
}

- Additional material is published online only. To view please visit the journal online (http://dx.doi.org/10.1136/ jclinpath-2016-204184).

Department of Cancer Screening, Centre for Epidemiology and Prevention in Oncology (CPO), University Hospital "Città della Salute e della Scienza di Torino", Turin, Italy

\section{Correspondence to} Dr Paola Armaroli, Department of Cancer Screening, Centre for Epidemiology and Prevention in Oncology (CPO), University Hospital "Città della Salute e della Scienza di Torino", Via Cavour 31, Turin 10123, Italy; paola.armaroli@cpo.it

Received 17 October 2016 Revised 12 December 2016 Accepted 13 December 2016

To cite: Segnan N, Minozzi S, Ponti A, et al. J Clin Pathol Published Online First: [please include Day Month Year] doi:10.1136/ jclinpath-2016-204184

\section{ABSTRACT}

Background False-positive histological diagnoses have the same consequences of overdiagnosis in terms of unnecessary treatment. The aim of this systematic review is to assess their frequency at needle core biopsy (CB) and/or surgical excision of the breast.

Methods PubMed, Embase, Cochrane Library were systematically searched up to 30 October 2015. Eligibility criteria: cross-sectional studies assessing diagnostic accuracy of CB compared with surgical excision; studies assessing reproducibility of pathologists reading the same slides. Outcomes: false-positive rates;

Misclassification of Benign as Malignant (MBM)

histological diagnosis; K statistic. Independent reviewers extracted data and assessed quality using an adapted QUADAS-2 tool.

Results Sixteen studies assessed CB false-positive rates. In 10 studies (41 989 screen-detected lesions), the range of false-positive rates was $0 \%-7.1 \%$. Twentyseven studies assessed pathologists' reproducibility. Studies with consecutive, random or stratified samples of all the specimens: at CB the MBM range was $0.25 \%$ $2.4 \%$ ( $\mathrm{K}$ values $0.83-0.98$ ); at surgical excision, it was $0.67 \%-1.2 \%$ ( $K$ values $0.86-0.94$ ). Studies with enriched samples: the MBM range was $1.4 \%-6.2 \%$ ( $\mathrm{K}$ values $0.57-0.86$ ). Studies of cases selected for second opinion: the MBM range was $0.29 \%-12.2 \%$ ( $\mathrm{K}$ values 0.48 and 0.50 ).

Conclusions High heterogeneity of the included studies precluded formal pooling estimates. When considering studies of higher sample size or methodological quality, false-positive rates and MBM are around $1 \%$. The impact of false-positive histological diagnoses of breast cancer on unnecessary treatment, as well as that of overdiagnosis, is not negligible and is of importance in clinical practice.

\section{INTRODUCTION}

Histopathology is currently the main criterion for cancer diagnosis. Consequently, diagnostic pathology errors, that is, misdiagnosis, may lead to incorrect patient management, including delays or unnecessary treatment. ${ }^{1}{ }^{2}$ Pathological diagnosis errors have been shown to exist for nearly every cancer type, ${ }^{3-5}$ and the effect of these errors on patient outcome is largely unknown. ${ }^{2}$ How to measure and reduce misdiagnosis is a theme of current debate. ${ }^{6-8}$

Implementation of population-based cancer screening has made more critical the issue of falsenegative and false-positive diagnoses. In the context of breast cancer $(\mathrm{BC})$, the introduction of mammographic screening and, more recently, of preoperative MRI, has dramatically increased the detection of non-palpable, minimally invasive carcinoma, ductal carcinoma in situ (DCIS) and borderline lesions, which are difficult to diagnose. Published interobserver reproducibility studies have shown low level of agreement among pathologists. ${ }^{9-13}$ Non-palpable breast lesions are generally diagnosed by core biopsy (CB). This technique allows to avoid a number of open breast biopsies, but the assessment of $\mathrm{CB}$ may be complicated, because a small amount of tissue is obtained. Yet, accurate and reproducible histopathology assessment of breast lesions is of crucial importance when deciding on optimal management choices, which may or may not include treatment.

Moreover, since early diagnosis markedly increases the number of patients with relatively favourable prognosis, concerns about false-positive histological diagnosis and the potential harm of unnecessary treatments for cancer have grown. False-positive histological diagnoses have the same consequences of overdiagnosis (diagnoses of 'cancers' that would not have harmed the patient during lifetime ${ }^{14}$ ), either in screen-detected or in clinically detected BCs.

In order to assess the risk of false-positive histological diagnoses of $\mathrm{BC}$ and the reproducibility of histological diagnoses, we systematically reviewed studies reporting data on the frequency of misclassification of $\mathrm{BC}$ in women with suspected malignant lesions undergoing needle $\mathrm{CB}$ and/or surgical excision.

\section{METHODS}

\section{Data sources and searches}

We searched on PubMed, Embase and Cochrane Library all from start date up to 30 October 2015 using a combination of mesh terms and free text words (see online supplementary appendix 1). No language restriction was applied. We inspected the reference lists of the retrieved studies and included relevant articles that we were aware of and that were not captured by our search. Articles suggested by the authors were added to the literature base.

\section{Study selection}

Included studies

- Cross-sectional studies assessing the diagnostic accuracy of histological examination of specimen from $\mathrm{CB}$; the $\mathrm{CB}$ (index test) was compared with the histological examination of specimen from surgical excision (reference standard) (group 1 studies).

- Studies assessing the agreement among pathologists reading the same $\mathrm{CB}$ or surgical excision slides (group 2 studies).

Participants were patients with a suspicion of invasive BC or DCIS, screen and clinically detected. We 
considered studies where cases were: (a) all patients consecutively recruited in a certain period of time, randomly selected or stratified samples for type of lesion; (b) enriched samples where a type of cancer or a type of diagnosis (ie, malignant or borderline) were intentionally over-represented or selected to increase the statistical power, when the method for over selection was clearly reported, (c) studies including only cases selected for second opinions. We excluded studies where the criteria and method of case selection were not reported or when the criteria were the selection of 'typical' or 'atypical' or particularly difficult to interpret or 'the most representative' lesion according to the subjective opinion of the study authors.

Outcomes of interest were:

Group 1 studies: the percentage of lesions reclassified from malignant to benign or from invasive cancer to DCIS at CB and surgical excision, respectively.

Group 2 studies: false-positive misclassification of histological diagnosis, the $\mathrm{K}$ statistic.

\section{Data extraction and quality assessment}

$\mathrm{CB}, \mathrm{SG}, \mathrm{MGL}, \mathrm{SM}$ independently selected potentially relevant studies by reading the search hits' titles and abstracts. SM, CB, NS, AP, PA independently assessed for inclusion each full text. CB, SG, MGL, PA extracted data. SM, PA, NS, AP, SB checked the data extraction. Doubts and disagreement were resolved by discussion.

SG, SM, SB independently assessed the methodological quality of the studies. For group 1 studies, we used the QUADAS-2 scale. ${ }^{15}$ For group 2 studies, we did not find in the literature any validated checklist specific for this kind of study. Also standards for reporting are lacking in the international literature; a new checklist for quality of reporting was proposed by a group of experts in 2011, not yet validated. ${ }^{16}$ So we used a modified checklist adapted from the QUADAS $^{17}$ to make it applicable to assess the quality of reliability and agreement studies, in a similar way already done in other systematic reviews. ${ }^{18}$

\section{Data synthesis and analysis}

For group 1 studies, we extracted data on the number of patients (or lesions) according to the following definitions:

- CB false-positive rate: that is, percentage of histological diagnoses reclassified from any malignant $\mathrm{BC}$ (invasive $\mathrm{BC}$ or DCIS) at $\mathrm{CB}$ to benign at surgical excision;

- lesions diagnosed as invasive carcinoma by $\mathrm{CB}$, reclassified as benign tumour by surgical excision;

- lesions diagnosed as DCIS by CB, reclassified as benign tumour by surgical excision.

- Lesions diagnosed as invasive carcinoma by $\mathrm{CB}$, downgraded to DCIS by surgical excision.

We excluded cases for which it was reported that the lesion found at $\mathrm{CB}$ or vacuum-assisted biopsy had been completely excised by the preoperative needle biopsy. Cases receiving neo-adjuvant chemotherapy were also excluded.

For group 2 studies, we extracted data on reproducibility of two (or more) readings of the same specimen calculating histological diagnosis misclassification from available data. When the readers were two, we did not consider one reading as reference unless clearly specified by the authors (ie, expert pathologist). When the readers were more than two, we considered as reference the majority diagnosis, or the consensus diagnosis, or second opinion, or expert diagnosis.

We calculated misclassification as follows:

- Misclassification of Benign lesions as Malignant (MBM): lesions classified as benign at the reference diagnosis and as malignant (DCIS and invasive) at the first diagnosis, on all lesions (or readings, according to available data).

- Misclassification of DCIS as invasive cancers: lesions classified as DCIS at the reference diagnosis and as invasive at first diagnosis, on the total of malignant lesions at reference.

- Misclassification of benign lesions as invasive: lesions classified as benign at the reference diagnosis and as invasive at first diagnosis, on the total of benign lesions at reference.

- Misclassification of benign lesions as DCIS: lesions classified as benign at the reference diagnosis and as DCIS at first diagnosis, on the total of benign lesions at reference,

When the reference was not clearly specified by the authors, we reported the number of discordant diagnoses.

The overall agreement, in terms of Cohen's kappa (K) or as defined by the authors was reported.

We reported results grouping the studies for the following characteristics:

Group 1: studies which included (a) only screen-detected lesions; (b) both screen and clinically detected lesions; (c) type of lesions included not specified.

Group 2: (a) studies with consecutively recruited samples in a certain period of time, randomly selected or stratified samples for type of lesion; (b) studies with enriched samples, where a type of cancer or a type of diagnosis (ie, malignant or borderline) were intentionally over-represented or selected; (c) studies including only cases selected for second opinions.

For each subgroup, the range of the outcomes results was reported. No meta-analyses were performed because of the high heterogeneity of the studies included.

\section{RESULTS}

\section{Results of the bibliographic search}

After removing duplicates, a total of 6932 records were identified through databases searches. A total 6828 records were excluded on the basis of titles and abstracts as clearly not relevant. One hundred and four articles were judged potentially relevant and acquired in full text. Seven further studies were suggested by the authors as potentially relevant. Sixty-seven articles were excluded (reasons for exclusion in online supplementary appendix 2). Forty-three studies were finally included (44 articles). ${ }^{9} 13$ 19-59 Dahlstrom et al and Sutton et $a l^{24}{ }^{46}$ reported the results of the same study (figure 1 Preferred Reporting Items for Systematic Reviews and MetaAnalyses (PRISMA) flow chart). One study was in French, three studies were in Portuguese, all the others in English.

\section{Characteristic of the included studies}

In table 1, the number of included studies are reported by type of design, sampling tissue methods and invasion status.

Group 1: studies comparing CB versus surgical excision

Sixteen studies (17 articles) involving a total of 44713 lesions in women receiving both $\mathrm{CB}$ and surgical excision, assessed the false-positive rate of histological examination of specimens from $\mathrm{CB}$ compared with surgical excision. ${ }^{22} 242628293536383941$ 46-50 $52 \quad 54$ Ten studies included screen-detected lesions. $^{22} 24282936394146-4850$ Three studies included both screen and clinically detected lesions. ${ }^{26} 3552$ Three studies did not report this information. ${ }^{3849} 54$ Recruitment ranged from 1990 to 2012. Detailed study characteristics are reported in online supplementary appendix 3 .

Group 2: studies assessing reproducibility of two or more readings of the same specimen

Twenty-seven studies, analysing a total of 13017 lesions, assessed the reproducibility of two or more readings of the same 


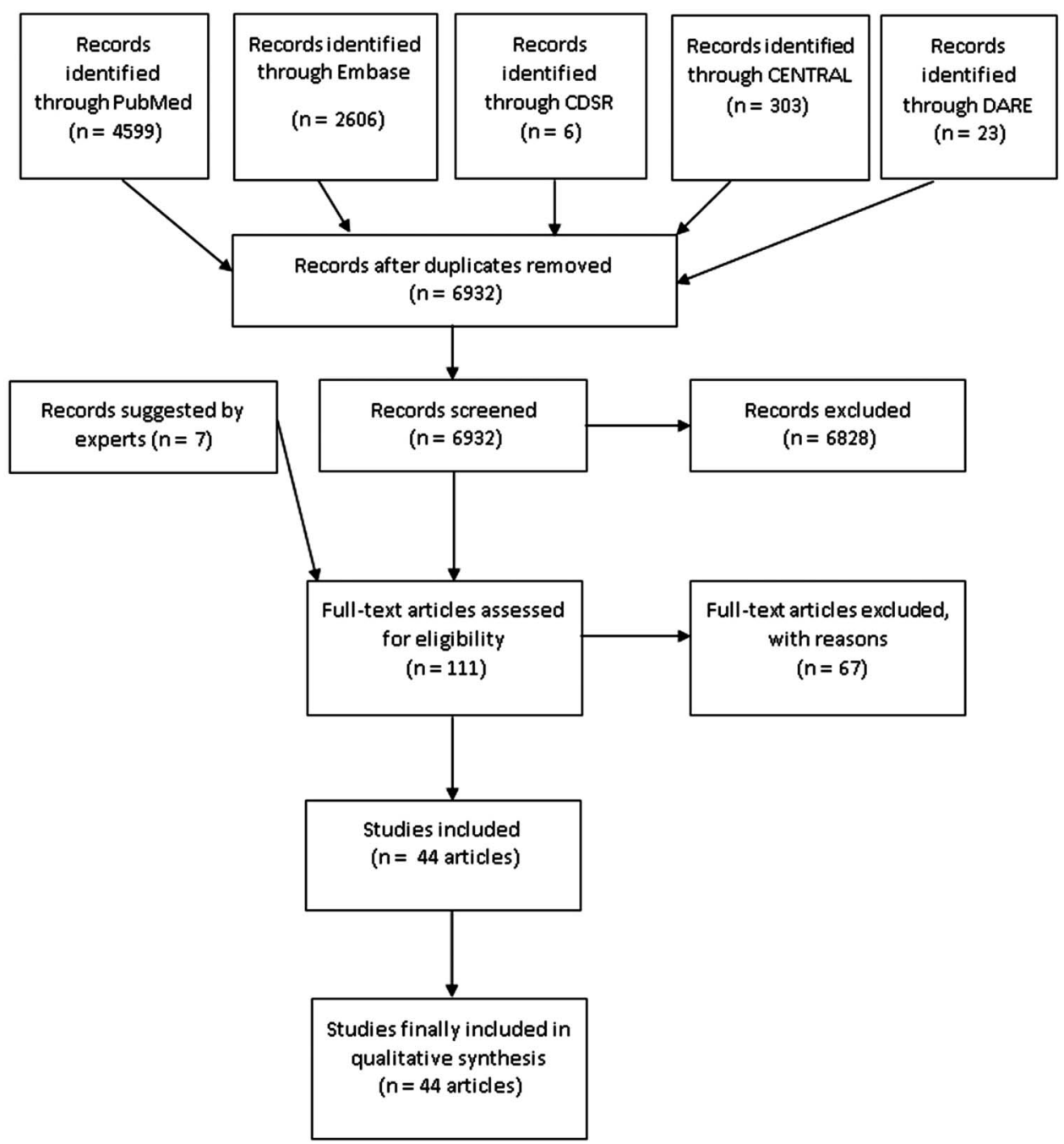

Figure 1 PRISMA flow chart. CENTRAL, Cochrane Central Register of Controlled Trials; CDSR, Cochrane Database of Systematic Reviews; DARE, Database of Abstracts of Reviews of Effects; PRISMA, Preferred Reporting Items for Systematic Reviews and Meta-Analyses.

Table 1 Number of included studies by type of design, sampling tissue methods and invasion status

\begin{tabular}{|c|c|c|c|}
\hline \multirow[b]{2}{*}{ Study design } & \multirow[b]{2}{*}{ Tissue sampling } & \multicolumn{2}{|l|}{ Neoplasia } \\
\hline & & $\begin{array}{l}\text { DCIS and invasive } \\
\text { BC separately }\end{array}$ & $\begin{array}{l}\text { Malignant } \\
\text { (invasive and DCIS) }\end{array}$ \\
\hline Validation-false-positive rate & CB vs surgical excision (total number=16) & 5 & 16 \\
\hline \multicolumn{4}{|l|}{ Reproducibility-misclassification } \\
\hline \multirow[t]{4}{*}{ Consecutive or random or stratified samples } & $\mathrm{CB}$ (total number=4) & 2 & 4 \\
\hline & Surgical excision (total number=3) & 2 & 3 \\
\hline & $\mathrm{CB}$ and surgical excision (total number $=1$ ) & 1 & 1 \\
\hline & Not reported (total number $=6^{*}$ ) & 2 & 4 \\
\hline \multirow[t]{4}{*}{ Enriched samples } & CB (total number=1) & 0 & 1 \\
\hline & Surgical excision (total number $=0$ ) & 0 & 0 \\
\hline & $\mathrm{CB}$ and surgical excision (total number $=1$ ) & 1 & 1 \\
\hline & Not reported (total number $=4$ ) & 4 & 4 \\
\hline \multirow[t]{4}{*}{ Second opinion } & $\mathrm{CB}$ (total number $=0$ ) & 0 & 0 \\
\hline & Surgical excision (total number $=2 \dagger$ ) & 0 & 1 \\
\hline & $C B$ and surgical excision (total number $=4$ ) & 4 & 4 \\
\hline & Not reported (total number=3) & 2 & 3 \\
\hline
\end{tabular}


Table 2 Core biopsy versus excision at surgery

\begin{tabular}{|c|c|c|c|c|c|c|c|c|c|c|}
\hline & \multicolumn{10}{|l|}{ 1a. Screen-detected lesions } \\
\hline & Britton et $a l l_{1}^{22} \mathrm{UK}$ & \multicolumn{2}{|c|}{$\begin{array}{l}\text { Dahistrom et al }{ }^{24} \\
\text { Sutton et } a l_{1}{ }^{66} \\
\text { Australia }\end{array}$} & $\begin{array}{l}\text { Jackman } \\
\text { et } \mathrm{al}_{1}^{28} \text { USA }\end{array}$ & Lifrange et $a l,{ }^{29}$ Belgiun & & \multicolumn{2}{|c|}{ Rakha et $a I_{1}^{36} \mathrm{UK}$} & $\begin{array}{l}\text { Seoudi et al }{ }^{41} \\
\text { USA }\end{array}$ & $\begin{array}{l}\text { Smyth and } \\
\text { Cederbom, }{ }^{39} \text { USA }\end{array}$ \\
\hline Diagnosis at $\mathrm{CB}$ & $\begin{array}{l}15 \text { inadequate (B1) } \\
0 \text { probably benign (B3): } \\
6 \text { probably malignant (B4) } \\
90 \text { malignant (B5) }\end{array}$ & \multicolumn{2}{|c|}{$\begin{array}{l}8 \text { atypical ductal } \\
\text { hyperplasia } \\
51 \text { in situ or } \\
\text { invasive cancers } \\
\text { - }\end{array}$} & $\begin{array}{l}296 \text { benign } \\
135 \text { carcinoma } \\
19 \text { atypical } \\
\quad \text { hyperplasia } \\
\text { - }\end{array}$ & Not reported & & \multicolumn{2}{|c|}{$\begin{array}{l}9400 \text { B5a (in situ } \\
\text { malignancy) } \\
30453 \text { B5b (invasive } \\
\text { malignancy) } \\
542 \text { B5C (in situ/invasive } \\
\text { malignancy) }\end{array}$} & $\begin{array}{l}16 \text { malignant } \\
8 \text { premalignant }\end{array}$ & $\begin{array}{l}44 \text { benign } \\
14 \text { malignant } \\
-\end{array}$ \\
\hline Diagnosis at surgical excision & $\begin{array}{l}10 \text { benign } \\
101 \text { malignant }\end{array}$ & \multicolumn{2}{|c|}{$\begin{array}{l}1 \text { atypical ductal } \\
\text { hyperplasia } \\
58 \text { malignant }\end{array}$} & $\begin{array}{l}37 \mathrm{DCIS} \\
45 \mathrm{IDC} \\
26 \mathrm{IDC} \text { and } \mathrm{EIC} \\
8 \mathrm{ILC}\end{array}$ & $\begin{array}{l}36 \text { benign } \\
64 \text { malignant ( } 2 \text { diagnose } \\
\text { surgical biopsy)1 patient } r\end{array}$ & $\begin{array}{l}\text { at second } \\
\text { used surgery }\end{array}$ & \multicolumn{2}{|c|}{$\begin{array}{l}40221 \text { malignant } \\
9 \text { benign } 165 \text { true removal of } \\
\text { the whole lesion at } C B\end{array}$} & $\begin{array}{l}23 \text { malignant or } \\
\text { premalignant } \\
3 \text { normal or benign } \\
1 \text { invasive ductal } \\
\text { carcinoma }\end{array}$ & $\begin{array}{l}13 \text { malignant } \\
45 \text { benign }\end{array}$ \\
\hline \multirow[t]{3}{*}{$\begin{array}{l}\text { False-positive rate: from malignant } \mathrm{BC} \\
\text { (invasive } \mathrm{BC} \text { or } \mathrm{DCIS} \text { ) at } \mathrm{CB} \text { to benign } \\
\text { at } \mathrm{SE}\end{array}$} & $\begin{array}{l}\text { Malignant defined as B4+B5: } \\
2.08 \% \\
(95 \% \mathrm{Cl} 0.25 \% \text { to } 7.32 \%) \\
\text { malignant defined as B5: } 0 \% \\
(97.5 \% \mathrm{Cl} 0 \% \text { to } 4.02 \%)\end{array}$ & \multicolumn{2}{|c|}{$\begin{array}{l}0 \% \\
(97.5 \% \mathrm{Cl} 0 \% \text { to } \\
6.98 \%)\end{array}$} & $\begin{array}{l}0 \% \\
(97.5 \% \text { Cl } 0 \% \text { to } \\
3.13 \%)\end{array}$ & 3/not reported & & \multicolumn{2}{|c|}{$\begin{array}{l}0.02 \% \\
(95 \% \mathrm{Cl} 0.01 \% \text { to } 0.04 \%)\end{array}$} & $\begin{array}{l}0 \% \\
(97.5 \% \text { Cl } 0 \% \text { to } \\
20.59 \%)\end{array}$ & $\begin{array}{l}7.14 \% \\
(95 \% \mathrm{Cl} 0.18 \% \text { to } \\
33.87 \%)\end{array}$ \\
\hline & \multicolumn{5}{|l|}{ 1a. Screen-detected lesions } & \multicolumn{5}{|c|}{ 1b. Screen and clinically detected lesions } \\
\hline & \multicolumn{2}{|l|}{ Taft $1996,{ }^{48}$ Australia } & \multicolumn{2}{|c|}{ Vega $1995,{ }^{50}$ Spain } & $\begin{array}{l}\text { Verkooijen } 2002,{ }^{47} \text { The } \\
\text { Netherlands }\end{array}$ & \multicolumn{2}{|c|}{$\begin{array}{l}\text { Frankel 2011, }{ }^{26} \\
\text { Brazil }\end{array}$} & \multicolumn{2}{|c|}{ Pijnappel 1997,35 The Netherlands } & $\begin{array}{l}\text { Wiratkapun 2010, } \\
\text { Thailand }\end{array}$ \\
\hline Diagnosis at $C B$ & \multicolumn{2}{|c|}{$\begin{array}{l}20 \text { benign } \\
106 \text { malignant (49 invasive ductal cancer, } 37 \\
\text { DCIS, } 15 \text { invasive lobular cancer, } 3 \text { lobular } \\
\text { cancer, } 2 \text { mixed ductal/lobular) }\end{array}$} & \multicolumn{2}{|c|}{$\begin{array}{l}32 \text { Invasive } \\
\text { carcinoma } \\
19 \text { carcinoma } \\
16 \text { atypia } \\
87 \text { benign } \\
2 \text { inadequate cases }\end{array}$} & $\begin{array}{l}352 \text { benign/normal } \\
26 \text { high risk } \\
190 \text { DCIS } \\
290 \text { invasive }\end{array}$ & \multicolumn{2}{|c|}{$\begin{array}{l}88 \text { malignant } \\
1 \text { unsatisfactory }\end{array}$} & \multicolumn{2}{|c|}{$\begin{array}{l}\text { Palpable lesions: } \\
22 \text { invasive cancers } \\
5 \text { benign } \\
\text { Non-palpable lesions: } \\
41 \text { malignancies } \\
35 \text { benign }\end{array}$} & $\begin{array}{l}43 \text { benign } \\
8 \text { high risk } \\
13 \text { malignancy }\end{array}$ \\
\hline Diagnosis at surgical excision & \multicolumn{2}{|l|}{$\begin{array}{l}108 \text { malignant } \\
18 \text { benign }\end{array}$} & \multicolumn{2}{|c|}{$\begin{array}{l}50 \text { invasive } \\
19 \text { non invasive } \\
87 \text { benign }\end{array}$} & $\begin{array}{l}342 \text { benign/normal } \\
28 \text { high risk } \\
168 \text { DCIS } \\
320 \text { invasive }\end{array}$ & \multicolumn{2}{|c|}{$\begin{array}{l}66 \text { benign } \\
92 \text { malignant }\end{array}$} & \multicolumn{2}{|c|}{$\begin{array}{l}\text { Palpable lesions: } \\
5 \text { benign } \\
22 \text { malignant } \\
\text { Non-palpable lesions: } \\
33 \text { benign } \\
43 \text { malignant }\end{array}$} & $\begin{array}{l}42 \text { benign } \\
5 \text { high risk } \\
17 \text { malignancy }\end{array}$ \\
\hline $\begin{array}{l}\text { False-positive rate: from malignant } \mathrm{BC} \\
\text { (invasive } \mathrm{BC} \text { or } \mathrm{DCIS} \text { ) at } \mathrm{CB} \text { to benign } \\
\text { at surgical excision }\end{array}$ & \multicolumn{2}{|l|}{$0.94 \%(95 \% \mathrm{Cl} 0.02 \%$ to $5.14 \%)$} & \multicolumn{2}{|c|}{$\begin{array}{l}0 \%(97.5 \% \mathrm{Cl} 0 \% \text { to } \\
\quad 6.98 \%)\end{array}$} & $\begin{array}{l}1.04 \%(95 \% \mathrm{Cl} 0.35 \% \text { to } \\
2.41 \%)\end{array}$ & \multicolumn{2}{|c|}{$\begin{array}{l}0 \%(97.5 \% \mathrm{Cl} 0 \% \text { to } \\
4.11 \%)\end{array}$} & \multicolumn{2}{|c|}{$\begin{array}{l}\text { Palpable lesions: } 0 \%(97.5 \% \mathrm{Cl} 0 \% \text { to } \\
15.44 \%) \text { Non-palpable lesions: } 0 \% \\
(97.5 \% \mathrm{Cl} 0 \% \text { to } 8.22 \%)\end{array}$} & $\begin{array}{l}0 \%(97.5 \% \mathrm{Cl} 0 \% \text { to } \\
24.71 \%)\end{array}$ \\
\hline
\end{tabular}




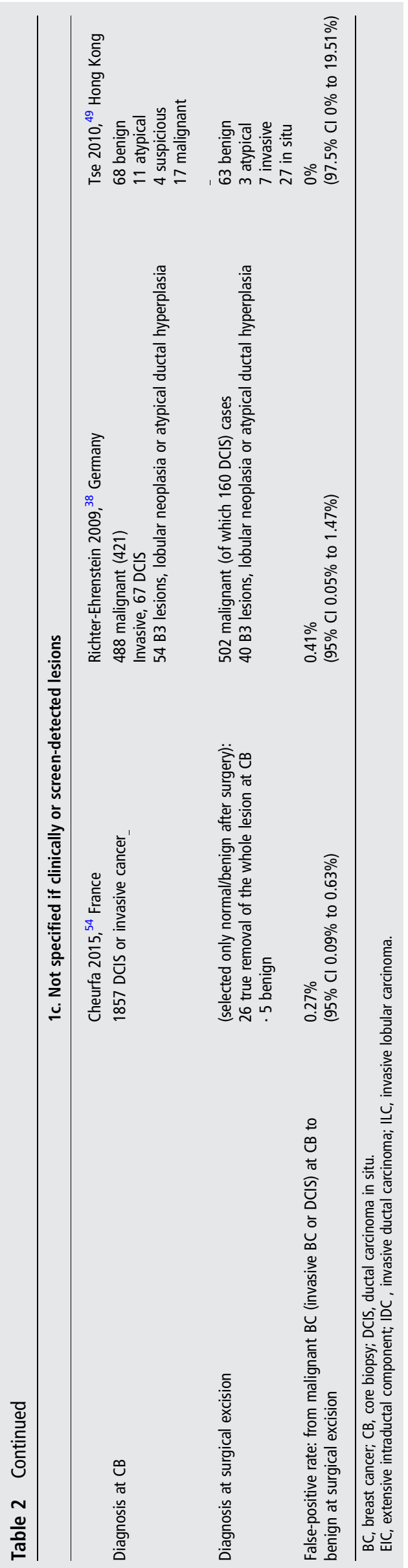

specimen among pathologists. Twelve studies included consecutively recruited or randomly selected or stratified

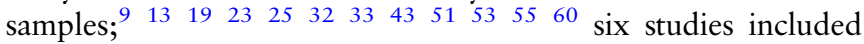
enriched samples; ${ }^{20} 21 \quad 274245 \quad 56$ nine studies included only cases selected for a second opinion. ${ }^{30} 313437404457-59$

Types of specimens analysed by type of design and invasion status are reported in table 1.

Two studies assessed the agreement between two readers; 3343 in 1 study $^{19}$ three readers reviewed slides; in 15 studies this information was not reported; $;^{2} 23303134374044455355 \quad 57-60$ in 9 studies, the same set of slides were reviewed by $10,{ }^{32}$ $12,,^{20} 2731,,^{21} 47,,^{13} 26,,^{51} 220-466^{25}$ and $186-251$ pathologists. ${ }^{42}$ Elmore et al reported agreement among the initial independent diagnoses of three expert consensus panel members (CPM), and the concordance between 115 pathologists and the consensus-derived reference diagnosis. ${ }^{56}$ Recruitment ranged from 1951 to 2014. Detailed study characteristics are reported in online supplementary appendix 3 .

\section{Methodological quality of included studies}

The overall risk-of-bias assessment for all included studies is reported in online supplementary appendix 4.

Group 1: studies comparing CB versus surgical excision

Twelve of the 16 studies were judged at low, 2 at unclear risk $^{29} 39$ and 2 at high ${ }^{24} 4648$ risk of patients selection bias. Concerning applicability, all the studies included patients who matched the review question. Thirteen out of sixteen studies were judged at low risk of bias for the conduct or interpretation of the index test; 2 studies were judged at high risk $^{24} \quad 46 \quad 48$ and 1 study was judged at unclear risk. ${ }^{52}$ Concerning applicability, there was low risk for all the studies that the index test, its conduct or interpretation differed from the review question. Thirteen out of sixteen studies were judged at unclear risk of bias for what concerns the conduct of interpretation of reference standard; Tse et $a l^{49}$ and Verkooijen $^{47}$ were judged at low risk of bias, Sutton et al, Dahlstrom et $a l^{24} 46$ and Rakha et $a l^{36}$ were judged at high risk of bias. Concerning applicability, there was low concern in all the studies that the target condition as defined by the reference standard does not match the review question. Seven out of sixteen studies were judged at low risk of bias $^{35} 363941495054$ for what concern the patients flow, and 9 at high risk of bias. ${ }^{22} 242628293846-4852$

Group 2: studies assessing reproducibility of two or more readings of the same specimen

All but one studies with consecutive or random or stratified samples were judged at low risk of cases selection bias; Palli et $a l^{33}$ was judged at unclear risk for what concern selection of cases because the sample was consecutively recruited for the Swedish series, but it was unclear for the Italian series; all the six studies with enriched samples were judged at high risk of cases selection bias; among the studies with cases selected for a second opinion, six studies were judged at low; $31374457-59$ the other ones at high risk of cases selection bias. Routine clinical data were available for interpretation

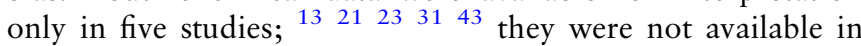
three studies; ${ }^{27} 3233$ it was unclear in the other studies. Thirteen out of 27 studies were judged at low risk of bias for what concern independent and blind evaluation of specimens; 3 studies $^{23} 3031$ were judged at high risk and the other ones at unclear risk. All but one study ${ }^{57}$ studies were judged at low risk of bias for patients flow. 
Table 2A Core biopsy versus excision at surgery, additional data, available only for screen-detected lesions

\begin{tabular}{|c|c|c|c|}
\hline Study & $\begin{array}{l}\text { From invasive at } C B \text { to benign } \\
\text { at surgical excision }\end{array}$ & $\begin{array}{l}\text { From } D C I S \text { at } C B \text { to benign } \\
\text { at surgical excision }\end{array}$ & $\begin{array}{l}\text { From invasive at } C B \text { to } D C I S \\
\text { at surgical excision }\end{array}$ \\
\hline Jackman et $a l_{,}^{28}$ USA & $0 \%(97.5 \% \mathrm{Cl} 0 \%$ to $4.93 \%)$ & $0 \%(97.5 \% \mathrm{Cl} 0 \%$ to $8.22 \%)$ & $2.74 \%(95 \% \mathrm{Cl} 0.33 \%$ to $9.55 \%)$ \\
\hline Lifrange et $a_{1}{ }_{1}^{29}$ Belgium & & $1 /$ not reported & $2 /$ not reported \\
\hline Rakha et al, ${ }^{36} \mathrm{UK}$ & $0.003 \%(95 \% \mathrm{Cl} 0.00008 \%$ to $0.018 \%)$ & $0.08 \%(95 \% \mathrm{Cl} 0.04 \%$ to $0.17 \%)$ & \\
\hline Taft et $a_{1}{ }^{48}$ Australia & $0.94 \%(95 \% \mathrm{Cl} 0.02 \%$ to $5.14 \%)$ & & \\
\hline Verkooijen, ${ }^{47}$ The Netherlands & $0.34 \%(95 \% \mathrm{Cl} 0.01 \%$ to $1.91 \%)$ & $2.10 \%(95 \% \mathrm{Cl} 0.58 \%$ to $5.30 \%)$ & $1.38 \%(95 \% \mathrm{Cl} 0.38 \%$ to $3.49 \%)$ \\
\hline
\end{tabular}

\section{Study results}

Group 1: studies comparing CB versus surgical excision

In table 2, results from studies comparing $\mathrm{CB}$ versus surgical excision are reported.

When considering studies assessing the false-positive rate of histological examination of screen-detected lesions, the range among 10 studies $22 \begin{array}{lllllll}28 & 29 & 36 & 39 & 41 & 46-48 & 50 \\ \text { including } & 41989\end{array}$ lesions in total was $0 \%-7.1 \%$. The false-positive rate was $0 \%$ in three studies ${ }^{26} 3552$ comparing histological examination at CB versus surgical excision among 325 total screen and clinically detected lesions, it ranged from $0 \%$ to $0.41 \%$ among three studies $^{384954}$ assessing 2499 lesions whose mode of detection was not reported.

Four studies ${ }^{22} \quad \begin{array}{llll}28 & 36 & 48 & \text { reported data on screen-detected }\end{array}$ lesions diagnosed as invasive carcinoma by $\mathrm{CB}$, classified as benign tumour by surgical excision (range 0\%-0.94\%); three studies $^{28} 3647$ reported data on lesions diagnosed as DCIS by $\mathrm{CB}$, classified as benign tumour by surgical excision (0\%-2.1\%).

Group 2: studies assessing reproducibility of two or more readings of the same specimen

In table 3 , results from studies assessing reproducibility of two or more readings of the same specimen are reported.

Among studies with consecutive or random or stratified samples of all the specimens, MBM of histological diagnosis at $\mathrm{CB}$ ranged from $0.25 \%$ to $2.4 \%$ (four studies), the range of $\mathrm{K}$ values was $0.83-0.98$ (four studies); at surgical excision MBM ranged from $0.67 \%$ to $1.2 \%$ (three studies), the $\mathrm{K}$ value from 0.86 to 0.94 (three studies); at $\mathrm{CB}$ and surgical excision it was estimated as $0.90 \%$ (one study), the $\mathrm{K}$ value as 0.71 ; when not reporting the type of specimen, MBM ranged from $0 \%$ to $4.8 \%$ (four studies), the $\mathrm{K}$ value from 0.35 to 0.91 (four studies). In the studies reporting also more detailed data, higher level of misclassification of benign lesion as DCIS is observed (range $0 \%-3.2 \%$ ) compared with the levels of misclassification of benign lesions as invasive cancers (range 0\%-1.04\%). Misclassification of DCIS as invasive cancers, when available, ranged from $0 \%$ to $10.8 \%$.

Among studies with enriched samples, MBM of histological diagnosis at $\mathrm{CB}$ was $4.4 \%$ (one study); at $\mathrm{CB}$ and surgical excision it was estimated as $6.2 \%$ when reporting data for 115 readers and as $4.03 \%$ for the 3 CPM (one study); among studies not reporting the type of specimen, MBM ranged from $1.4 \%$ to $3.7 \%$ (four studies). The $\mathrm{K}$ values range was $0.57-0.86$ (five studies). More detailed data were reported by Elmore et al: ${ }^{56}$ misclassification of benign lesions as invasive cancers at $\mathrm{CB}$ and surgical excision was estimated as $0.70 \%$ when reporting data for 115 readers and as $0.23 \%$ for the 3 CPM; higher values of misclassification of benign lesions as DCIS $(9.6 \%$ when reporting data for 115 readers and as $6.5 \%$ for the 3 CPM) were observed.

Among studies with only cases selected for a second opinion MBM of histological diagnosis at surgical excision was estimated $0.35 \%$ (one study); at CB and surgical excision it ranged from $0.93 \%$ to $11 \%$ (four studies); among studies not reporting the type of specimen MBM ranged from $0.29 \%$ to $12.16 \%$ (three studies). The $\mathrm{K}$ values were 0.48 and 0.50 (two studies).

\section{DISCUSSION}

The objective of the review was to assess the frequency of falsepositive histological diagnosis of $\mathrm{BC}$ in women undergoing $\mathrm{CB}$ and/or surgical excision. We included two groups of studies: (1) 16 studies, involving a total of 44713 lesions, assessing the accuracy and the false-positive rate of histological examination from CB compared with histological examination from surgical excision; (2) 27 studies, analysing a total of 13017 lesions, assessing the reproducibility of two or more readings of the same specimen among pathologists.

In studies on screen-detected lesions assessing $\mathrm{CB}$ accuracy compared with surgical excision as reference standard, the falsepositive rate ranged from $0 \%$ to $7.1 \%$. In studies with consecutive or random or stratified samples of all the specimens assessing the diagnostic reproducibility among pathologists, the MBM of histological diagnoses ranged from $0.25 \%$ to $4.8 \%$. Higher levels of misclassifications were observed for DCIS, and among studies with enriched samples or with cases selected for a second opinion.

The major flaws of studies assessing CB accuracy compared with surgical excision concerned the patients flow and the conduct or interpretation of the reference standard results. The major flaws of studies assessing diagnostic reproducibility among pathologists concerned the method of sample selection and the lack of independent blind evaluation of specimens.

The strength of this review relies in the fact that it provides an overview of all the studies assessing the diagnostic misclassification, in screen and clinically detected BCs retrieved by a comprehensive bibliographic search, in a field which is relatively understudied. ${ }^{61}$ On the other hand, a limitation is the high heterogeneity of the included studies, which precluded to formally combine their results in order to give an overall estimate of false-positive histological diagnosis and misclassification rates.

Results from the studies assessing the diagnostic accuracy of CB compared with surgical excision, and from the studies assessing the diagnostic reproducibility among pathologists are different. The majority of the studies comparing $\mathrm{CB}$ with surgical excision were conducted with consecutive or representative samples taken from routine practice. If, from this point of view, selection bias is unlikely, on the other side for the majority of them it is unclear whether the pathological diagnosis from surgical excision was blind from or only confirmatory of CB. Also, 
Table 3 Reproducibility of two readings of the same specimen

\begin{tabular}{|c|c|c|c|c|c|c|}
\hline Study & $\begin{array}{l}\text { No. of lesion or patients } \\
\text { No. of readers } \\
\text { No. of total readings }\end{array}$ & $\begin{array}{l}\text { DCIS misclassified as } \\
\text { invasive on the total of } \\
\text { malignant (DCIS and } \\
\text { invasive) lesions (\%) }\end{array}$ & $\begin{array}{l}\text { Benign lesions misclassified } \\
\text { as invasive on the total of } \\
\text { benign lesions (\%) }\end{array}$ & $\begin{array}{l}\text { Benign lesions misclassified } \\
\text { as DCIS on the total of } \\
\text { benign lesions (\%) }\end{array}$ & $\begin{array}{l}\text { Benign lesions misclassified as malignant } \\
\text { (invasive and DCIS) on the total of } \\
\text { readings (or lesions, according to the } \\
\text { available data) (MBM) (\%) }\end{array}$ & $\begin{array}{l}\text { K value (when specified) or } \\
\text { overall agreement or overall } \\
\text { disagreement }\end{array}$ \\
\hline \multicolumn{7}{|c|}{ 2a. Patients consecutively recruited or randomly selected samples or stratified samples } \\
\hline \multicolumn{7}{|c|}{ Type of specimen: core needle biopsies } \\
\hline \multicolumn{7}{|c|}{ Screen-detected lesions } \\
\hline $\begin{array}{l}\text { Collins et al, } \\
\text { USA }\end{array}$ & $\begin{array}{l}\text { No. of lesion or patients: } 2004 \\
\text { patients } \\
\text { No. of readers: NR } \\
\text { No. of total readings: } 2004\end{array}$ & $2.55 \%$ & $0.12 \%$ & $0.19 \%$ & $0.25 \%$ & $\begin{array}{l}\text { Overall agreement } \\
96.06 \%(95 \% \mathrm{Cl} 95.11 \% \text { to } \\
96.87 \%) \\
\text { K overall } \\
0.90(95 \% \mathrm{Cl} 0.88 \% \text { to } 0.92 \%)\end{array}$ \\
\hline $\begin{array}{l}\text { Soofi and } \\
\text { Khoury, }{ }^{60} \text { USA }\end{array}$ & $\begin{array}{l}\text { No. of lesion or patients: } 502 \\
\text { lesions } \\
\text { No. of readers: NR } \\
\text { No. of total readings: } 502\end{array}$ & NA & NA & NA & $2.39 \%$ & $\begin{array}{l}\text { Overall agreement } \\
79.28 \%(95 \% \mathrm{Cl} 75.47 \% \text { to } \\
82.74 \%)\end{array}$ \\
\hline \multicolumn{7}{|c|}{ Screen and clinically detected lesions } \\
\hline $\begin{array}{l}\text { Verkooijen } \\
\text { et al, }{ }^{13} \text { The } \\
\text { Netherlands }\end{array}$ & $\begin{array}{l}\text { No. of lesion or patients: } 718 \\
\text { lesions ( } 688 \text { patients) } \\
\text { No. of readers: } 47 \\
\text { No. of total readings: } 718\end{array}$ & $1.37 \%$ & $0.36 \%$ & $3.20 \%$ & $1.39 \%$ & $\begin{array}{l}\text { Overall agreement } \\
88.02 \%(95 \% \mathrm{Cl} 85.42 \% \text { to } \\
90.31 \%) \\
\text { K overall } \\
0.83(95 \% \mathrm{Cl} 0.78 \text { to } 0.88)\end{array}$ \\
\hline $\begin{array}{l}\text { Stang et al, }{ }^{43} \\
\text { Germany }\end{array}$ & $\begin{array}{l}\text { No. of lesion or patients: } 765 \\
\text { patients } \\
\text { No. of readers: } 2 \\
\text { No. of total readings: } 765\end{array}$ & NA & NA & NA & $1.96 \%$ number of discordant diagnoses & $\begin{array}{l}\text { K overall } \\
\text { Five-level B-categorisation } \\
\text { scheme: } 0.89 \text { ( } 95 \% \text { Cl } 0.86 \text { to } \\
0.91 \text { ) } \\
\text { Two-level B-categorisation } \\
\text { scheme: } 0.86 \text { ( } 95 \% \text { Cl: } 0.83 \text { to } \\
\text { 0.90) }\end{array}$ \\
\hline \multicolumn{7}{|c|}{ Type of specimen: surgical specimens } \\
\hline \multicolumn{7}{|c|}{ Screen-detected lesions } \\
\hline $\begin{array}{l}\text { Collins et al }{ }^{9} \\
\text { USA }\end{array}$ & $\begin{array}{l}\text { No. of lesion or patients: } 2004 \\
\text { patients } \\
\text { No. of readers: NR } \\
\text { No. of total readings: } 596\end{array}$ & $1.49 \%$ & $1.04 \%$ & $2.59 \%$ & $1.17 \%$ & $\begin{array}{l}\text { Overall agreement: } \\
92.62 \% \text { ( } 95 \% \mathrm{Cl} 90.22 \% \text { to } \\
94.58 \%) \\
\mathrm{K} \text { overall } 0.89 \text { ( } 95 \% \mathrm{Cl} 0.86 \text { to } \\
\text { 0.92) }\end{array}$ \\
\hline \multicolumn{7}{|c|}{ Screen and clinically detected lesions } \\
\hline $\begin{array}{l}\text { Verkooijen } \\
\text { et } a l^{13} \text { The } \\
\text { Netherlands }\end{array}$ & $\begin{array}{l}\text { No. of lesion or patients: } 718 \\
\text { lesions ( } 688 \text { patients) } \\
\text { No. of readers: } 47 \\
\text { No. of total readings: } 718\end{array}$ & $1.55 \%$ & $0 \%$ & $1.89 \%$ & $0.69 \%$ & $\begin{array}{l}\text { Overall agreement } \\
90.39 \%(95 \% \mathrm{Cl} 88.00 \% \text { to } \\
92.45 \%) \\
\text { K overall } 0.86(95 \% \mathrm{Cl} 0.81 \text { to } \\
0.91)\end{array}$ \\
\hline \multicolumn{7}{|c|}{ Not specified if screen or clinically detected lesions } \\
\hline $\begin{array}{l}\text { Middleton } \\
\text { et } a l_{,}^{55} \text { USA }\end{array}$ & $\begin{array}{l}\text { No. of lesion or patients: } 297 \\
\text { lesions } \\
\text { No. of readers: NR } \\
\text { No. of total readings: } 297\end{array}$ & NA & NA & NA & $0.67 \%$ & $\begin{array}{l}\text { Overall agreement } \\
86.53 \%(95 \% \mathrm{Cl} 82.11 \% \text { to } \\
90.20 \%)\end{array}$ \\
\hline \multicolumn{7}{|c|}{ Type of specimen: core needle biopsies and surgical specimens } \\
\hline
\end{tabular}




\begin{tabular}{|c|c|c|c|c|c|c|}
\hline Study & $\begin{array}{l}\text { No. of lesion or patients } \\
\text { No. of readers } \\
\text { No. of total readings }\end{array}$ & $\begin{array}{l}\text { DCIS misclassified as } \\
\text { invasive on the total of } \\
\text { malignant (DCIS and } \\
\text { invasive) lesions (\%) }\end{array}$ & $\begin{array}{l}\text { Benign lesions misclassified } \\
\text { as invasive on the total of } \\
\text { benign lesions (\%) }\end{array}$ & $\begin{array}{l}\text { Benign lesions misclassified } \\
\text { as DCIS on the total of } \\
\text { benign lesions (\%) }\end{array}$ & $\begin{array}{l}\text { Benign lesions misclassified as malignant } \\
\text { (invasive and DCIS) on the total of } \\
\text { readings (or lesions, according to the } \\
\text { available data) (MBM) (\%) }\end{array}$ & $\begin{array}{l}\mathrm{K} \text { value (when specified) or } \\
\text { overall agreement or overall } \\
\text { disagreement }\end{array}$ \\
\hline \multicolumn{7}{|c|}{ Not specified if screen or clinically detected lesions } \\
\hline $\begin{array}{l}\text { Wells et al, } \\
\text { USA }\end{array}$ & $\begin{array}{l}\text { No. of lesion or patients: } 30 \\
\text { lesions } \\
\text { No. of readers: } 26 \\
\text { No. of total readings: } 780\end{array}$ & $10.84 \%$ & $0.35 \%$ & $0.89 \%$ & $0.90 \%$ & $\begin{array}{l}\text { K core needle biopsies: } 0.98 \\
\text { K surgical specimens: } 0.94 \\
\text { K overall: } 0.71 \\
\text { Overall agreement } \\
36.67 \%(95 \% \mathrm{Cl} 19.93 \% \text { to } \\
56.14 \%)\end{array}$ \\
\hline \multicolumn{7}{|c|}{ Type of specimen: not reported } \\
\hline $\begin{array}{l}\text { Anderson et al, }{ }^{19} \\
\text { UK }\end{array}$ & $\begin{array}{l}\text { No. of lesion or patients: } 875 \\
\text { lesions } \\
\text { No. of readers: } 3 \text { pathologists } \\
\text { reviewed slides in batches of } \\
80-100 \text { cases } \\
\text { No. of total readings: } 875\end{array}$ & NA & NA & NA & $0.57 \%$ & $\begin{array}{l}\text { Overall agreement } \\
94.9 \%(95 \% \mathrm{Cl} 93.27 \% \text { to } \\
96.30 \%) \mathrm{K} \text { non-invasive/ } \\
\text { microinvasive }=0.84 \\
\mathrm{~K} \text { non-invasive/invasive }=0.91\end{array}$ \\
\hline \multicolumn{7}{|c|}{ Not specified if screen or clinically detected lesions } \\
\hline $\begin{array}{l}\text { Chang et } a l_{1}^{23} \\
\text { Pennsylvania }\end{array}$ & $\begin{array}{l}\text { No. of lesion or patients: } 77 \\
\text { lesions ( } 75 \text { patients) } \\
\text { No. of readers: NR } \\
\text { No. of total readings: } 76\end{array}$ & $0 \%$ & $0 \%$ & $0 \%$ & $0 \%$ & $\begin{array}{l}\text { Overall agreement } \\
96.10 \%(95 \% \mathrm{Cl} 89.03 \% \text { to } \\
99.19 \%)\end{array}$ \\
\hline Ellis et $a l_{,}^{25} \mathrm{UK}$ & $\begin{array}{l}\text { No. of lesion or patients: } 12 \\
\text { lesions } \\
\text { No. of readers: } 686 \text { in two } \\
\text { circulation } \\
\text { No. of total readings: not } \\
\text { applicable }\end{array}$ & NA & NA & NA & NA & K overall 0.78 \\
\hline $\begin{array}{l}\text { Palazzo and } \\
\text { Hyslop, }^{32} \text { USA }\end{array}$ & $\begin{array}{l}\text { No. of lesion or patients: } 31 \\
\text { lesions } \\
\text { No. of readers: } 10 \\
\text { No. of total readings: } 310\end{array}$ & NA & NA & NA & $4.84 \%$ number of discordant diagnoses & $\begin{array}{l}\text { K overall } 0.347 \\
\text { K overall among } 8 \text { pathologists } \\
\text { who used standardised criteria } \\
0.360\end{array}$ \\
\hline $\begin{array}{l}\text { Palli et al, } \\
\text { Sweden and Italy }\end{array}$ & $\begin{array}{l}\text { No. of lesion or patients: } 372 \\
\text { lesions } \\
\text { No. of readers: } 2 \\
\text { No. of total readings: not } \\
\text { applicable }\end{array}$ & $\begin{array}{l}4.30 \% \text { number of discordant } \\
\text { diagnoses }\end{array}$ & NA & NA & NA & $\begin{array}{l}\text { Overall agreement } \\
73.92 \%(95 \% \mathrm{Cl} 69.15 \% \text { to } \\
78.31 \%) \\
\text { K overall } 0.53\end{array}$ \\
\hline $\begin{array}{l}\text { Zieger and } \\
\text { Stein, }{ }^{53} \text { Germany }\end{array}$ & $\begin{array}{l}\text { No. of lesion or patients: } 1500 \\
\text { lesions ( } 3 \text { groups of } 500 \\
\text { consecutive biopsies each) } \\
\text { No. of readers: NR } \\
\text { No. of total readings: } 1500\end{array}$ & NA & NA & NA & $0.13 \%$ & \\
\hline \multicolumn{7}{|c|}{ 2b. Enriched samples } \\
\hline \multicolumn{7}{|c|}{ Type of specimen: core needle biopsies } \\
\hline
\end{tabular}


Table 3 Continued

\begin{tabular}{|c|c|c|c|c|c|c|}
\hline Study & $\begin{array}{l}\text { No. of lesion or patients } \\
\text { No. of readers } \\
\text { No. of total readings }\end{array}$ & $\begin{array}{l}\text { DCIS misclassified as } \\
\text { invasive on the total of } \\
\text { malignant (DCIS and } \\
\text { invasive) lesions (\%) }\end{array}$ & $\begin{array}{l}\text { Benign lesions misclassified } \\
\text { as invasive on the total of } \\
\text { benign lesions (\%) }\end{array}$ & $\begin{array}{l}\text { Benign lesions misclassified } \\
\text { as DCIS on the total of } \\
\text { benign lesions (\%) }\end{array}$ & $\begin{array}{l}\text { Benign lesions misclassified as malignant } \\
\text { (invasive and DCIS) on the total of } \\
\text { readings (or lesions, according to the } \\
\text { available data) (MBM) (\%) }\end{array}$ & $\begin{array}{l}\mathrm{K} \text { value (when specified) or } \\
\text { overall agreement or overall } \\
\text { disagreement }\end{array}$ \\
\hline $\begin{array}{l}\text { Bianchi et } a l_{r}^{21} \\
\text { Italy }\end{array}$ & $\begin{array}{l}\text { No. of lesion or patients: } 50 \\
\text { lesions } \\
\text { No. of readers: } 31 \\
\text { No. of total readings: } 1550\end{array}$ & NA & NA & NA & $\begin{array}{l}4.39 \% \\
\text { (considering as benign B2 and B3 and } \\
\text { malignant B4-B5) }\end{array}$ & $\begin{array}{l}\text { K overall } 0.61 \text { (range } 0.31 \text { - } \\
0.88 \text { ) }\end{array}$ \\
\hline \multicolumn{7}{|c|}{ Type of specimen: core needle biopsies and surgical specimens } \\
\hline \multicolumn{7}{|c|}{ Not specified if screen or clinically detected lesions } \\
\hline $\begin{array}{l}\text { Elmore et } a l_{1}^{56} \\
\text { USA }\end{array}$ & $\begin{array}{l}\text { No. of lesion or patients: } 240 \\
\text { lesions ( } 4 \text { test sets of } 60 \\
\text { breast biopsies), } \\
\text { No. of readers: } 115,3 \text { CPM } \\
\text { No. of total readings: } 6900 \text {; } \\
720\end{array}$ & $\begin{array}{l}\text { Results from } 115 \text { readers: } \\
1.96 \% \\
\text { Results from } 3 \text { CPM: } 0.69 \%\end{array}$ & $\begin{array}{l}\text { Results from } 115 \text { readers: } \\
0.70 \% \\
\text { Results from } 3 \text { CPM: } \\
0.23 \%\end{array}$ & $\begin{array}{l}\text { Results from } 115 \text { readers: } \\
9.64 \% \\
\text { Results from } 3 \text { CPM: } \\
6.48 \%\end{array}$ & $\begin{array}{l}\text { Results from } 115 \text { readers: } 6.20 \% \\
\text { Results from } 3 \text { CPM: } 4.03 \%\end{array}$ & $\begin{array}{l}\text { Results from } 115 \text { readers: } \\
\text { Overall agreement: } 75.3 \% \text {, } \\
\text { (95\% Cl } 73.4 \% \text { to } 77.0 \%) \\
\text { Results from } 3 \mathrm{CPM}: \\
\text { Unanimous agreement of their } \\
\text { independent diagnoses } 75 \% \\
\text { Concordance with the } \\
\text { consensus-derived reference } \\
\text { diagnoses } 90.3 \%\end{array}$ \\
\hline \multicolumn{7}{|c|}{ Type of specimen: not reported } \\
\hline \multicolumn{7}{|c|}{ Screen-detected lesions } \\
\hline $\begin{array}{l}\text { Bianchi et } a l_{,}^{20} \\
\text { Italy }\end{array}$ & $\begin{array}{l}\text { No. of lesion or patients: } 25 \\
\text { lesions } \\
\text { No. of readers: } 12 \\
\text { No. of total readings: } 300\end{array}$ & $3.47 \%$ & $3.85 \%$ & $0 \%$ & $2.00 \%$ & K overall 0.86 (range $0.65-1.0$ ) \\
\hline $\begin{array}{l}\text { Sloane et } a l_{,}{ }^{42} \\
\text { UK }\end{array}$ & $\begin{array}{l}\text { No. of lesion or patients: } 12 \\
\text { lesions } \\
\text { No. of readers: } 186-251 \\
\text { No. of total readings: } 17545\end{array}$ & $2.31 \%$ & $1.05 \%$ & $2.23 \%$ & $1.36 \%$ & $\begin{array}{l}\text { K overall } \\
\text { Coordinators } 0.86 \\
\text { Non-coordinators } 0.78\end{array}$ \\
\hline \multicolumn{7}{|c|}{ Not specified if screen or clinically detected lesions } \\
\hline Beck $^{45}$ UK & $\begin{array}{l}\text { No. of lesion or patients: } 40 \\
\text { lesions } \\
\text { No. of readers: } 9 \\
\text { No. of total readings: } 360\end{array}$ & $\begin{array}{l}\text { First circulation }=0 \% \\
\text { Second circulation }=0 \%\end{array}$ & $\begin{array}{l}\text { First circulation }=0.89 \% \\
\text { Second circulation }=0 \%\end{array}$ & $\begin{array}{l}\text { First circulation }=4.44 \% \\
\text { Second circulation }=4.17 \%\end{array}$ & $\begin{array}{l}\text { First circulation }=3.33 \% \\
\text { Second circulation }=2.5 \%\end{array}$ & $\begin{array}{l}\text { K overall } \\
0.57 \text { (value for both circulation } \\
\text { and two borderline series } \\
\text { combined) }\end{array}$ \\
\hline $\begin{array}{l}\text { Giardina et al, } \\
\text { Italy }\end{array}$ & $\begin{array}{l}\text { No. of lesion or patients: } 88 \\
\text { lesions No. of readers: } 12 \\
\text { No. of total readings: } 1032\end{array}$ & $0 \%$ & $4.38 \%$ & $3.19 \%$ & $3.68 \%$ & $\begin{array}{l}\text { K overall } \\
\text { Between pathologist }=0.66 \\
\text { (range } 0.57-0.76 \text { ) } \\
\text { Between pathologist and the } \\
\text { predominant diagnosis }=0.786 \\
\text { (SE } 0.27 \text { ) }\end{array}$ \\
\hline \multicolumn{7}{|c|}{ 2c. Second opinion } \\
\hline \multicolumn{7}{|c|}{ Type of specimen: surgical specimens } \\
\hline \multicolumn{7}{|c|}{ Not specified if screen or clinically detected lesions } \\
\hline $\begin{array}{l}\text { Khazai et al }{ }^{59} \\
\text { USA }\end{array}$ & $\begin{array}{l}\text { No. of lesion or patients: } 1970 \\
\text { lesions } \\
\text { No. of readers: NR } \\
\text { No. of total readings: } 1970\end{array}$ & NA & NA & NA & $0.35 \%$ & - \\
\hline
\end{tabular}


Table 3 Continued

\begin{tabular}{|c|c|c|c|c|c|c|}
\hline Study & $\begin{array}{l}\text { No. of lesion or patients } \\
\text { No. of readers } \\
\text { No. of total readings }\end{array}$ & $\begin{array}{l}\text { DCIS misclassified as } \\
\text { invasive on the total of } \\
\text { malignant (DCIS and } \\
\text { invasive) lesions (\%) }\end{array}$ & $\begin{array}{l}\text { Benign lesions misclassified } \\
\text { as invasive on the total of } \\
\text { benign lesions (\%) }\end{array}$ & $\begin{array}{l}\text { Benign lesions misclassified } \\
\text { as DCIS on the total of } \\
\text { benign lesions (\%) }\end{array}$ & $\begin{array}{l}\text { Benign lesions misclassified as malignant } \\
\text { (invasive and DCIS) on the total of } \\
\text { readings (or lesions, according to the } \\
\text { available data) (MBM) (\%) }\end{array}$ & $\begin{array}{l}\mathrm{K} \text { value (when specified) or } \\
\text { overall agreement or overall } \\
\text { disagreement }\end{array}$ \\
\hline $\begin{array}{l}\text { Renshaw and } \\
\text { Gould, }{ }^{37} \text { USA }\end{array}$ & $\begin{array}{l}\text { No. of lesion or patients: } 1131 \\
\text { lesions } \\
\text { No. of readers: NR } \\
\text { No. of total readings: NA }\end{array}$ & $\begin{array}{l}3 / \text { not reported the number of } \\
\text { malignant }\end{array}$ & NA & NA & NA & - \\
\hline \multicolumn{7}{|c|}{ Type of specimen: core needle biopsies and surgical specimens } \\
\hline \multicolumn{7}{|c|}{ Not specified if screen or clinically detected lesions } \\
\hline $\begin{array}{l}\text { Gomes et al, } \\
\text { Brazil }\end{array}$ & $\begin{array}{l}\text { No. of lesion or patients: } 610 \\
\text { lesions } \\
\text { No. of readers: not reported } \\
\text { No. of total readings: } 610\end{array}$ & NA & NA & $11.41 \%$ & $6.23 \%$ & \\
\hline $\begin{array}{l}\text { Marco et al, } \\
\text { Spain }\end{array}$ & $\begin{array}{l}\text { No. of lesion or patients: } 205 \\
\text { lesions } \\
\text { No. of readers: NR } \\
\text { No. of total readings: } 205\end{array}$ & $5.59 \%$ & $11.76 \%$ & $0 \%$ & $0.98 \%$ & $\begin{array}{l}\text { Overall agreement } \\
74.63 \%(95 \% \mathrm{Cl} 68.00 \% \text { to } \\
80.44 \%)\end{array}$ \\
\hline $\begin{array}{l}\text { Perez et al }{ }^{34} \\
\text { Brazil }\end{array}$ & $\begin{array}{l}\text { No. of lesion or patients: } 209 \\
\text { lesion } \\
\text { No. of readers: NR } \\
\text { No. of total readings: } 209\end{array}$ & $6.62 \%$ & $5.17 \%$ & $34.48 \%$ & $11.00 \%$ & $\begin{array}{l}\text { Overall agreement } \\
83.25 \%(95 \% \mathrm{Cl} 77.49 \% \text { to } \\
88.05 \%) \\
\text { K overall } 0.5\end{array}$ \\
\hline $\begin{array}{l}\text { Romanoff et al, }{ }^{58} \\
\text { USA }\end{array}$ & $\begin{array}{l}\text { No. of lesion or patients: } 430 \\
\text { lesions ( } 306 \text { patients) } \\
\text { No. of readers: NR } \\
\text { No. of total readings: } 430\end{array}$ & $0.74 \%$ & NA & $2.48 \%$ & $0.93 \%$ & $\begin{array}{l}\text { Overall agreement } \\
83.26 \%(95 \% \mathrm{Cl} 79.38 \% \text { to } \\
86.66 \%)\end{array}$ \\
\hline \multicolumn{7}{|c|}{ Type of specimen: not reported } \\
\hline \multicolumn{7}{|c|}{ Not specified if screen or clinically detected lesions } \\
\hline $\begin{array}{l}\text { Salles et al, }{ }^{40} \\
\text { Brazil }\end{array}$ & $\begin{array}{l}\text { No. of lesion or patients: } 329 \\
\text { lesions } \\
\text { No. of readers: NR } \\
\text { No. of total readings: } 329\end{array}$ & $12.00 \%$ & $7.75 \%$ & $23.26 \%$ & $12.16 \%$ & $\begin{array}{l}\text { Overall agreement } \\
59.88 \%(95 \% \mathrm{Cl} 54.36 \% \text { to } \\
65.22 \%) \\
\text { K overall } 0.48\end{array}$ \\
\hline $\begin{array}{l}\text { Newman et } a l_{1}^{31} \\
\text { Michigan }\end{array}$ & $\begin{array}{l}\text { No. of lesion or patients: } 149 \\
\text { patients } \\
\text { No. of readers: } \\
\text { multidisciplinary tumour board } \\
\text { No. of total readings: } 149\end{array}$ & NA & NA & NA & $4.03 \%$ & $\begin{array}{l}\text { Overall agreement } \\
71.14 \%(95 \% \mathrm{Cl} 63.16 \% \text { to } \\
78.26 \%)\end{array}$ \\
\hline $\begin{array}{l}\text { Staradub et al }{ }_{1}{ }^{44} \\
\text { USA }\end{array}$ & $\begin{array}{l}\text { No. of lesion or patients: } 346 \\
\text { lesions ( } 340 \text { patients) } \\
\text { No. of readers: NR } \\
\text { No. of total readings: } 346\end{array}$ & $2.03 \%$ & NA & NA & $0.29 \%$ & $\begin{array}{l}\text { Overall agreement } \\
80.35 \%(95 \% \mathrm{Cl} 75.76 \% \text { to } \\
84.40 \%)\end{array}$ \\
\hline
\end{tabular}

DCIS, ductal carcinoma in situ; NA, not applicable; NR, not reported. 
the experimental context of the studies does not completely reflect clinical practice, in which, for example, there maybe access to second opinion. Moreover, the majority of these studies report results based on small samples. Among studies assessing screen-detected lesions, only two studies ${ }^{36} 47$ have large sample sizes. Yet results of Rakha $e^{2} \mathrm{al}^{36}$ are not comparing histological diagnosis at $\mathrm{CB}$ and surgical excision in a blind way, assessing false-positive $\mathrm{CB}$ diagnosis by collecting further several types of data (ie, radiological ultrasound and clinical opinion, number of $\mathrm{CB}$ attempts, number of open surgical procedures to reach a final diagnosis). Taking into account sample size and methodological quality, among the studies assessing the false-positive rate of $\mathrm{CB}$ for screen-detected lesions, Verkooijen ${ }^{47}$ can be considered an informative study reporting a false-positive rate of $1.04 \%$. A false-positive rate of $0.89 \%$ could be estimated adding the results of all the other studies, with a small sample size, ${ }^{22} 24283941464850$ comparing histological diagnosis at CB and surgical excision for screen-detected lesions. Notwithstanding the high heterogeneity of the design of the studies, a similar overall rough estimate of MBM (0.93\%) could be obtained adding the results of all the studies assessing the diagnostic reproducibility among pathologists with consecutive or random or stratified or enriched samples of all the specimens of screen-detected lesions. Considering separately the type of specimen assessed, when adding results of MBM of histological diagnosis at CB only, the estimate is $1.05 \%$; it is $0.87 \%$, when adding results from studies on histological diagnosis at surgical excision only.

To our knowledge, no other systematic reviews with this scope have been published so far. We made every effort to identify all the published literature on this topic by performing sensitive and broad bibliographic searches without any language and date restriction and by contacting authors asking for further information when necessary. Nevertheless, publication bias cannot be ruled out, mainly for these types of studies for which the protocol registration is not required.

Based on the evidence of our review, false-positive histological diagnoses increase unnecessary treatment, in either screen or clinically detected BCs. Although the concordance for invasive $\mathrm{BC}$ in the results by Elmore ${ }^{62}$ was very good with a discordance of $2.3 \%$, and taking into account that it is very difficult to differentiate between atypia and DCIS, in the same study the variability in the interpretation of individual breast biopsy slides suggest that overinterpretation of the pathological findings may contribute to overtreatment. ${ }^{8}$ It has been reported that for women having breast biopsy, nearly one in five (18.5\%) with a diagnosis of DCIS would have their biopsy specimen interpreted as atypia or benign by the study's reference consensus panel (with the limiting assumptions that the diagnostic features were present on a single slide and no second opinions were obtained). ${ }^{62}$ Moreover in epidemiological studies, a great variation was observed in BC detection rate in population with similar incidence rates. Standardised (European population) total detection rate $(\times 100000)$, for women aged 50-69 years, at repeat screening test in 2010 ranges from 2.8 to 5 among the regions in North Italy ${ }^{63}$ Similarly, considerable international variation was found in DCIS detection. The age-standardised detection rate for DCIS varied from 1.6 to 0.45 (per 1000) among 15 screening settings in 12 countries. $^{64}$ This variation could not be fully explained by variation in invasive BC incidence or detection rates. One potential cause of such a great difference could be attributed to variability in pathological interpretation. Difficulties in pathological classifications and a poor relationship between morphological features and prognosis cause an appreciable fraction of overdiagnosed cases of BC. ${ }^{8}$ Indeed, for example, disagreements in pathological interpretation and classification of intraductal proliferative lesions, as well as in diagnosing microinvasion, could be considered as potential sources of overdiagnosis ${ }^{86}$ and overtreatment. ${ }^{65}$ The false-positive results represent an important harm, with implications for the diagnostic process both for screen and clinically detected lesions. They should be reduced to a minimum, since a diagnosis of a malignant neoplasia implies management decisions and may result in referral to unnecessary and often complex and costly interventions ${ }^{7}$ including surgery, radiation or, for false-positive invasive cancers, chemotherapy. In order to better quantify the actual burden of false-positive histological diagnoses, it would be beneficial to conduct studies in which independent reading of slides and consecutive cases or representative samples of cases are analysed. Quality controls of the diagnostic process, including systematic independent reading or second systematic opinion of biopsy samples for borderline lesions of the breast, may reduce the amount of overdiagnosis in asymptomatic populations. Further research is needed to better investigate the implications of these findings for patient management, the causes of the problem and possible remedies.

\section{CONCLUSIONS}

When considering studies of higher sample size or methodological quality only, the frequency of histological misclassification of breast benign lesions to malignant lesions in women undergoing core biopsy or surgical excision ranges around $1 \%$, meaning that of 100 positive core biopsies one is false positive and that of 100 surgical open biopsies with any diagnosis one is false positive. The impact of false-positive histological diagnosis on unnecessary treatment, as well as that of overdiagnosis, ${ }^{66}$ is not negligible and of importance in clinical practice.

\section{Take home messages}

- False positive histological diagnoses have the same consequences of overdiagnosis (diagnoses of "cancers" that would not have harmed the patient during lifetime) either in screen or in clinically detected breast cancers, in terms of overtreatment.

- The aim of this systematic review is to assess false positive histological diagnoses frequency at needle core-biopsy and/ or surgical excision.

- When considering studies of higher sample size or methodological quality, false positive rates and misclassification of benign as malignant histological diagnosis are around $1 \%$.

- The impact of false positive histological diagnoses of breast cancer on unnecessary treatment, as well as that of overdiagnosis, is not negligible and is of importance in clinical practice.

\section{Handling editor Cheok Soon Lee}

Contributors All the authors contributed in conceptualising the work, performing abstract and full-text review, synthesising the results and drafting and reviewing the manuscript. NS: developed the hypothesis of the study. PA, AP: contributed to study concept. SM: coordinated and revised the review process. $\mathrm{CB}$ : performed the literature search. SB: statistical support. SM, CB, PA, MG-L, SG: screened articles for inclusion, abstracted and synthesised data, assessed the methodological quality.

Funding This work was supported by the Centre for Epidemiology and Prevention in Oncology_Piedmont (year 2014, N. 188), National Health Service. 
Competing interests None declared.

Provenance and peer review Not commissioned; externally peer reviewed.

Data sharing statement Technical appendices are available from the corresponding author at paola.armaroli@cpo.it.

\section{REFERENCES}

1 Clary KM, Silverman JF, Liu Y, et al. Cytohistologic discrepancies: a means to improve pathology practice and patient outcomes. Am J Clin Pathol 2002;117:567-73.

2 Raab SS, Nakhleh RE, Ruby SG. Patient safety in anatomic pathology: measuring discrepancy frequencies and causes. Arch Pathol Lab Med 2005;129:459-66.

3 Llewellyn H. Observer variation, dysplasia grading, and HPV typing: a review. Am J Clin Pathol 2000;114(Suppl):S21-35.

4 Schlemper RJ, Kato Y, Stolte M. Review of histological classifications of gastrointestinal epithelial neoplasia: differences in diagnosis of early carcinomas between Japanese and Western pathologists. J Gastroenterol 2001;36:445-56.

5 Carlson GD, Calvanese CB, Kahane H, et al. Accuracy of biopsy Gleason scores from a large uropathology laboratory: use of a diagnostic protocol to minimize observer variability. Urology 1998:51:525-9.

6 National Academies of Sciences $\mathrm{E}$, and Medicine. Improving diagnosis in health care. Washington, DC: The National Academies Press, 2015.

7 Khullar D, Jha AK, Jena AB. Reducing diagnostic errors-why now? N Engl J Med 2015:373:2491-3.

8 Colin C, Devouassoux-Shisheboran M, Sardanelli F. Is breast cancer overdiagnosis also nested in pathologic misclassification? Radiology 2014;273:652-5.

9 Collins LC, Connolly JL, Page DL, et al. Diagnostic agreement in the evaluation of image-guided breast core needle biopsies: results from a randomized clinical trial. Am J Surg Pathol 2004;28:126-31.

10 Elston CW, Sloane JP, Amendoeira I, et al. Causes of inconsistency in diagnosing and classifying intraductal proliferations of the breast. European Commission Working Group on Breast Screening Pathology. Eur J Cancer 2000;36:1769-72.

11 Palli D, Galli M, Bianchi S, et al. Reproducibility of histological diagnosis of breast lesions: results of a panel in Italy. Eur J Cancer 1996;32A:603-7.

12 Rosai J. Borderline epithelial lesions of the breast. Am J Surg Pathol 1991;15:209-21.

13 Verkooijen HM, Peterse JL, Schipper ME, et al. Interobserver variability between general and expert pathologists during the histopathological assessment of large-core needle and open biopsies of non-palpable breast lesions. Eur J Cancer 2003:39:2187-91.

14 Welch HG, Black WC. Overdiagnosis in cancer. J Natl Cancer Inst 2010:102:605-13.

15 Whiting PF, Rutjes AW, Westwood ME, et al. QUADAS-2: a revised tool for the quality assessment of diagnostic accuracy studies. Ann Intern Med 2011;155:529-36.

16 Kottner J, Audige L, Brorson S, et al. Guidelines for Reporting Reliability and Agreement Studies (GRRAS) were proposed. J Clin Epidemiol 2011;64:96-106.

17 Whiting P, Rutjes AW, Reitsma JB, et al. The development of QUADAS: a tool for the quality assessment of studies of diagnostic accuracy included in systematic reviews. BMC Med Res Methodol 2003;3:25

18 Burr JM, Botello-Pinzon P, Takwoingi Y, et al. Surveillance for ocular hypertension: an evidence synthesis and economic evaluation. Health Technol Assess 2012:16:1-271, iii-iv.

19 Anderson TJ, Sufi F, Ellis IO, et al. Implications of pathologist concordance for breast cancer assessments in mammography screening from age 40 years. Hum Pathol 2002:33:365-71.

20 Bianchi S, Palli D, Galli M, et al. Reproducibility of histological diagnoses and diagnostic accuracy of non palpable breast lesions. Pathol Res Pract 1994;190:69-76.

21 Bianchi S, Caini S, Cattani MG, et al. Diagnostic concordance in reporting breast needle core biopsies using the B classification-a panel in Italy. Pathol Oncol Res 2009;15:725-32

22 Britton PD, Flower CD, Freeman AH, et al. Changing to core biopsy in an NHS breast screening unit. Clin Radiol 1997;52:764-7.

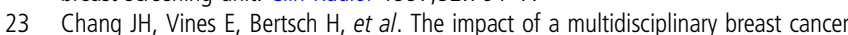
center on recommendations for patient management: the University of Pennsylvania experience. Cancer 2001;91:1231-7.

24 Dahlstrom JE, Jain S, Sutton T, et al. Diagnostic accuracy of stereotactic core biopsy in a mammographic breast cancer screening programme. Histopathology 1996:28:421-7.

25 Ellis 10 , Coleman D, Wells C, et al. Impact of a national external quality assessment scheme for breast pathology in the UK. J Clin Pathol 2006;59:138-45.

26 Frankel PP, Esteves VF, Thuler LC, et al. [Diagnostic accuracy of the fine needle aspiration cytology and core needle biopsy as a diagnostic method for breast lesions]. Rev Bras Ginecol Obstet 2011;33:139-43.

27 Giardina C, Clemente R, Fusilli $\mathrm{S}$, et al. Interobserver reproducibility in diagnosis of breast lesions. A panel in Puglia (Italy). GSBioCaM. Tumori 1998;84:354-9.
28 Jackman RJ, Nowels KW, Shepard MJ, et al. Stereotaxic large-core needle biopsy of 450 nonpalpable breast lesions with surgical correlation in lesions with cancer or atypical hyperplasia. Radiology 1994;193:91-5.

29 Lifrange E, Kridelka F, Colin C. Stereotaxic needle-core biopsy and fine-needle aspiration biopsy in the diagnosis of nonpalpable breast lesions: controversies and future prospects. Eur J Radiol 1997;24:39-47.

30 Marco V, Muntal T, Garcia-Hernandez F, et al. Changes in breast cancer reports after pathology second opinion. Breast J 2014;20:295-301.

31 Newman EA, Guest $A B$, Helvie MA, et al. Changes in surgical management resulting from case review at a breast cancer multidisciplinary tumor board. Cancer 2006:107:2346-51.

32 Palazzo JP, Hyslop T. Hyperplastic ductal and lobular lesions and carcinomas in situ of the breast: reproducibility of current diagnostic criteria among community- and academic-based pathologists. Breast J 1998;4:230-7.

33 Palli D, Bianchi $\mathrm{S}$, Linell $\mathrm{F}$, et al. Histopathologic classification of breast cancer in Sweden and Italy: a comparison between two pathologists. Tumori 1992;78:247-9.

34 Perez AA, Balabram D, Salles Mde A, et al. [Consultation in breast surgical pathology: interobserver diagnostic variability of atypical intraductal proliferative lesions]. Rev Bras Ginecol Obstet 2013:35:164-70.

35 Pijnappel RM, van Dalen A, Borel Rinkes $1 \mathrm{H}$, et al. The diagnostic accuracy of core biopsy in palpable and non-palpable breast lesions. Eur J Radiol 1997;24:120-3.

36 Rakha EA, El-Sayed ME, Reed J, et al. Screen-detected breast lesions with malignant needle core biopsy diagnoses and no malignancy identified in subsequent surgical excision specimens (potential false-positive diagnosis). Eur J Cancer 2009;45:1162-7.

37 Renshaw AA, Gould EW. Reducing false-negative and false-positive diagnoses in anatomic pathology consultation material. Arch Pathol Lab Med 2013;137:1770-3.

38 Richter-Ehrenstein C, Muller S, Noske A, et al. Diagnostic accuracy and prognostic value of core biopsy in the management of breast cancer: a series of 542 patients. Int J Surg Pathol 2009;17:323-6.

39 Smyth AT, Cederbom GJ. Core biopsy of breast lesions. J La State Med Soc 1994;146:499-501.

40 Salles Mde A, Sanches FS, Perez AA, et al. [Importance of a second opinion in breast surgical pathology and therapeutic implications]. Rev Bras Ginecol Obstet 2008;30:602-8

41 Seoudi H, Mortier J, Basile R, et al. Stereotactic core needle biopsy of nonpalpable breast lesions: initial experience with a promising technique. Arch Surg 1998;133:366-72.

42 Sloane JP, Ellman R, Anderson TJ, et al. Consistency of histopathological reporting of breast lesions detected by screening: findings of the U.K. National External Quality Assessment (EQA) Scheme. U.K. National Coordinating Group for Breast Screening Pathology. Eur J Cancer 1994;30A:1414-19.

43 Stang A, Trocchi P, Ruschke K, et al. Factors influencing the agreement on histopathological assessments of breast biopsies among pathologists. Histopathology 2011;59:939-49.

44 Staradub VL, Messenger KA, Hao N, et al. Changes in breast cancer therapy because of pathology second opinions. Ann Surg Oncol 2002;9:982-7.

45 Beck JS. Observer variability in reporting of breast lesions. J Clin Pathol 1985:38:1358-65.

46 Sutton S, Dahlstrom JE, Jain S. Stereotactic large-gauge core biopsy: its role in the diagnosis of non-palpable mammographic abnormalities presenting to a screening service. Australas Radiol 1997:41:103-8.

47 Verkooijen HM. Diagnostic accuracy of stereotactic large-core needle biopsy for nonpalpable breast disease: results of a multicenter prospective study with $95 \%$ surgical confirmation. Int J Cancer 2002;99:853-9.

48 Taft $\mathrm{R}$, Chao K, Dear $\mathrm{P}$, et al. The role of core biopsy in the diagnosis of mammographically detected lesions. Aust N Z J Surg 1996;66:664-7.

49 Tse GM, Tan P-H, Lacambra MD, et al. Papillary lesions of the breast-accuracy of core biopsy. Histopathology 2010;56:481-8.

50 Vega A, Arrizabalaga R, Garijo F, et al. Nonpalpable breast lesion. Stereotaxic core needle aspiration biopsy with a single pass. Acta Radiol 1995;36:117-21.

51 Wells WA, Carney PA, Eliassen MS, et al. Statewide study of diagnostic agreement in breast pathology. J Natl Cancer Inst 1998:90:142-5.

52 Wiratkapun C, Fusuwankaya E, Wibulpholprasert B, et al. Diagnostic accuracy of vacuum-assisted stereotactic core needle biopsy for breast lesions. J Med Assoc Thai 2010;93:1058-64.

53 Zieger $\mathrm{G}$, Stein $\mathrm{H}$. Retrospective analysis of 1500 mamma biopsies from 1951-1975. A way of self-control in pathology. Pathol Res Pract 1982;173: 275-82.

54 Cheurfa N, Giard S. [Non-palpable breast cancer malignant on needle core biopsy and no malignancy in surgical excision: how to manage?]. Gynecol Obstet Fertil 2015:43:18-24.

55 Middleton LP, Feeley TW, Albright HW, et al. Second-opinion pathologic review is a patient safety mechanism that helps reduce error and decrease waste. J Oncol Pract 2014; 10:275-80

56 Elmore JG, Longton GM, Carney PA, et al. Diagnostic concordance among pathologists interpreting breast biopsy specimens. JAMA 2015;313:1122-32. 
57 Gomes DS, Porto SS, Balabram D, et al. Inter-observer variability between general pathologists and a specialist in breast pathology in the diagnosis of lobular neoplasia, columnar cell lesions, atypical ductal hyperplasia and ductal carcinoma in situ of the breast. Diagn Pathol 2014;9:121.

58 Romanoff AM, Cohen A, Schmidt $\mathrm{H}$, et al. Breast pathology review: does it make a difference? Ann Surg Oncol 2014;21:3504-8.

59 Khazai L, Middleton LP, Goktepe N, et al. Breast pathology second review identifies clinically significant discrepancies in over 10\% of patients. J Surg Oncol 2015;111:192-7.

60 Soofi Y, Khoury T. Inter-institutional pathology consultation: the importance of breast pathology subspecialization in a setting of tertiary cancer center. Breast J 2015;21:337-44.

61 Davidson NE, Rimm DL. Expertise vs evidence in assessment of breast biopsies: an atypical science. JAMA 2015;313:1109-10.
62 Elmore JG, Nelson HD, Pepe MS, et al. Variability in pathologists' interpretations of individual breast biopsy slides: a population perspective. Ann Intern Med 2016;164:649-55.

63 Giorgi D, Giordano L, Ventura L, et al. [Mammography breast cancer screening in Italy: 2010 survey]. Epidemiol Prev 2012;36(Suppl 1):8-27.

64 Lynge $E$, Ponti $A$, James $T$, et al. Variation in detection of ductal carcinoma in situ during screening mammography: a survey within the International Cancer Screening Network. Eur I Cancer 2014;50:185-92.

65 Ponti $A$, Lynge $E$, James $T$, et al. International variation in management of screen-detected ductal carcinoma in situ of the breast. Eur I Cancer 2014;50:2695-704

66 Segnan N, Minozzi S, Armaroli P, et al. Epidemiologic evidence of slow growing, nonprogressive or regressive breast cancer: a systematic review. Int I Cancer 2016;139:554-73. 


\section{Estimate of false-positive breast cancer diagnoses from accuracy studies: a systematic review}

Nereo Segnan, Silvia Minozzi, Antonio Ponti, Cristina Bellisario, Sara

Balduzzi, Marien González-Lorenzo, Silvia Gianola and Paola Armaroli

J Clin Pathol published online January 10, 2017

Updated information and services can be found at:

http://jcp.bmj.com/content/early/2017/01/10/jclinpath-2016-204184

\section{These include:}

Supplementary Material

References

Email alerting service
Supplementary material can be found at:

http://jcp.bmj.com/content/suppl/2017/01/10/jclinpath-2016-204184.D C1.html

This article cites 65 articles, 8 of which you can access for free at: http://jcp.bmj.com/content/early/2017/01/10/jclinpath-2016-204184 \#BIBL

Receive free email alerts when new articles cite this article. Sign up in the box at the top right corner of the online article.

\section{Notes}

To request permissions go to:

http://group.bmj.com/group/rights-licensing/permissions

To order reprints go to:

http://journals.bmj.com/cgi/reprintform

To subscribe to BMJ go to:

http://group.bmj.com/subscribe/ 